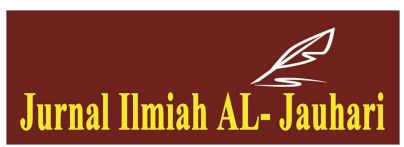

Jurnal Ilmiah ALo-Jauhari: Jurnal Studi Islam dan Interdisipliner

Volume 4 No 2, (Desember 2019): Halaman 283-312

ISSN (Print): 2541-3430, ISSN (Online): 2541-3449

Website: http://journal.iaingorontalo.ac.id/index.php/aj

\title{
Implementasi Model Pembelajaran Tematik Scientific dalam Meningkatkan Minat Belajar Peserta Didik
}

\author{
Rusni Walangadi \\ (Guru Sekolah Dasar Negeri 11 Kabila Bone Bolango) \\ rusniwalangadi@gmail.com
}

\begin{abstract}
This paper discusses the other side of the application of scientific thematic learning models in increasing the learning interest of students at SDN 2 Kabila, Bone Bolango Regency. The method used is descriptive qualitative. Thematic Learning by: (a) studentcentered, (b) Giving participants directly to students, (c) using invisible subjects, (d) presenting different subject concepts from the learning process, (e) flexible protection, (f) learning outcomes can be developed according to the interests and needs of students.

The factor hampering the application of thematic learning models in scientific discussion is the overcrowding of material available in each theme, so that the determined time is deemed inadequate by the teacher. Efforts made by teachers are to do additional hours of study Exit school hours of learning, as well as ask for time allowances on teachers of religious subjects, and sports.
\end{abstract}

\section{Abstrak}

Tulisan ini bertujuan mengungkap sisi lain dari penerapan model pembelajaran tematik scientific dalam meningkatkan minat belajar peserta didik di SDN 2 Kabila Kabupaten Bone Bolango. 
Metode yang dipergunakan adalah kualitatif deskriptif. Hasilnya menunjukkan bahwa pembelajaran terpadu yang menggunakan tema untuk mengaitkan beberapa mata pelajaran sehingga dapat memberikan pengalaman bermakna kepada peserta didik, sehingga menghasilkan pembelajaran tematik dengan: (a) berpusat pada peserta didik, (b) memberikan pengalaman langsung kepada peserta didik, (c) pemisahan antar mata pelajaran tidak nampak, (d) menyajikan konsep dari berbagai mata pelajaran dalam suatu proses pembelajaran., (e) bersifat luwes (fleksibel), (f) hasil pembelajaran dapat berkembang sesuai dengan minat dan kebutuhan peserta didik.

Faktor menghambat penerapan model pembelajaran tematik dalam pendekatan scientific adalah terlalu padatnya materi yang ada dalam setiap tema, sehingga waktu yang sudah ditetapkan dirasa kurang cukup oleh guru. Upaya yang dilakukan guru adalah dengan melaksanakan tambahan jam belajar diluar jam belajar sekolah, serta meminta kelonggaran waktu pada guru mata pelajaran agama, dan olahraga.

Kata Kunci: model pembelajaran, tematik scientific, minat belajar.

\section{Pendahuluan}

Sistem pendidikan nasional selalu mengalami perubahan sesuai dengan kebutuhan dan perkembangan zaman. Salah satu komponen penting dari sistem pendidikan adalah kurikulum, dengan adanya kebutuhan dan perkembangan zaman secara langsung akan mempengaruhi konsep kurikulum pendidikan yang diberlakukan. Berdasarkan kurikulum itulah proses pendidikan diharapkan dapat berjalan dengan arah dan tujuan yang benar.

Kurikulum yang ada di Indonesia saat ini mengalami peralihan dari kurikulum KTSP ke kurikulum 2013. Menurut Undang-undang Nomor 20 Tahun 2003 Pasal 1 Ayat 19, kurikulum merupakan seperangkat rencana dan pengaturan mengenai tujuan, isi, dan bahan pelajaran serta cara yang digunakan sebagai pedoman penyelenggaraan kegiatan pembelajaran untuk mencapai tujuan pendidikan. Tujuan pendidikan nasional adalah untuk mengembangkan potensi peserta didik agar menjadi manusia yang beriman dan bertakwa kepada Tuhan Yang Maha Esa, berakhlak mulia, sehat, berilmu, cakap, kreatif, mandiri, dan menjadi warga negara yang demokratis serta bertanggung jawab. Untuk mencapai tujuan pendidikan tersebut, seorang guru harus bisa menciptakan pembelajaran yang bermakna, sehingga peserta didik mampu

\section{Rusni Walangadi}


menguasai materi yang dipelajari dengan baik, serta dapat mengimplementasikannya di dalam kehidupan sehari-hari. Seorang guru juga harus mampu menanamkan dan mengembangkan nilai-nilai karakter pada diri peserta didik, sesuai dengan fungsi pendidikan nasional bahwa untuk mengembangkan kemampuan dan membentuk karakter serta peradaban bangsa yang bermartabat dalam rangka mencerdaskan kehidupan bangsa. ${ }^{1}$

Untuk mencapai tujuan pendidikan tersebut, seorang guru harus bisa menciptakan pembelajaran yang bermakna, sehingga peserta didik mampu menguasai materi yang dipelajari dengan baik, serta dapat mengimplementasikannya di dalam kehidupan sehari-hari. Seorang guru juga harus mampu menanamkan dan mengembangkan nilai-nilai karakter pada diri peserta didik di sekolah. Sekolah adalah lembaga formal tempat seorang peserta didik menimba ilmu dalam mengembangkan bakat, minat dan kemampuannya. Untuk mencapai keberhasilan di masa depan, pendidikan merupakan hal yang sangat penting.

Salah satu tujuan Pendidikan Nasional yang akan dan harus dicapai Bangsa Indonesia seperti yang termaktub dalam pembukaan UUD 1945 adalah mencerdaskan kehidupan bangsa. Upaya untuk mencerdaskan kehidupan bangsa tersebut, salah satunya dapat terlaksana melalui pendidikan. Metode pembelajaran adalah suatu cara atau jalan yang ditempuh yang sesuai dan serasi untuk menyajikan suatu hal sehingga akan tercapai suatu tujuan pembelajaran yang efektif dan efisien sesuai yang diharapkan. ${ }^{2}$ Menurut Wardati dan Jauhar Muhammad, bahwa salah satu pengertian pendidikan yang umum memaknai bahwa pendidikan adalah upaya memanusiakan manusia muda. Pengangkatan manusia muda ketaraf insan harus diwujudkan dalam seluruh proses atau upaya pendidikan. ${ }^{3}$

Di samping itu, Kementerian Pendidikan dan Kebudayaan (Kemendikbud) menegaskan bahwa kurikulum 2013 juga mengamanatkan untuk mendorong peserta didik agar mampu lebih baik dalam melakukan observasi, bertanya, menalar, dan mengkomunikasikan terhadap apa yang mereka peroleh atau mereka

\footnotetext{
${ }^{1}$ Sulaiman Ibrahim, Menata Pendidikan Islam di Indonesia: Sebuah Upaya Menuju Pendidikan yang Memberdayakan. HUNAFA: Jurnal Studia Islamika, 8 (1), (2011, June 15). 81-100. https://doi.org/https://doi.org/10.24239/jsi.v8i1.87.

${ }^{2}$ Ismail, 2008. Strategi Pembelajaran Agama Islam berbasis Paikem. Semarang: RaSAIL Media Group, h. 8.

${ }^{3}$ Wardati dan Jauhar Mohammad. 2011. Implementasi Bimbingan dan Konseling di Sekolah. Prestasi Pustakaraya, Jakarta, h. 150.
} 
ketahui setelah menerima materi pembelajaran. ${ }^{4}$. Intinya, yang menjadi ciri khas pembelajaran dalam Kurikulum 2013 adalah pembelajaran berbasis pendekatan scientific yang saat ini tentunya menarik untuk dipelajari dan diteliti lebih lanjut oleh para pendidik maupun pemerhati pendidikan.

Pendekatan scientific menjadikan pembelajaran lebih aktif dan tidak membosankan, peserta didik dapat mengonstruksi pengetahuan dan keterampilannya melalui fakta-fakta yang ditemukan dalam penyelidikan di lapangan guna pembelajaran. Selain itu, dengan pembelajaran berbasis pendekatan scientific ini, peserta didik didorong lebih mampu dalam mengobservasi, bertanya, bernalar, dan mengomunikasikan atau mempresentasikan hal-hal yang dipelajari dari fenomena alam ataupun pengalaman langsung. ${ }^{5}$

Kondisi pendidikan peserta didik di SDN 2 Kabila Kabupaten Bone Bolango, boleh dikatakan belum memiliki kualitas yang begitu baik. Hal ini dapat diukur dari hasil prestasi belajar peserta didik yang sangat rendah. Alasan lainnya adalah karena sarana prasarana yang belum memadai, mutu guru, dan kondisi ekonomi peserta didik. Berbicara mengenai pemilihan dan pendekatan pembelajaran yang sesuai erat kaitannya dengan mutu seorang guru. Mutu seorang guru dapat diukur melalui kemahiran dan profesionalitas seorang guru dalam merancang sebuah pembelajaran yang efektif dan efisien.

Keefektifan dan keefisienan sebuah pembelajaran diukur dari tingkat pemahaman materi oleh peserta didik yang berujung pada peningkatan prestasi belajar peserta didik. Untuk itu peran guru adalah memilih pendekatan pembelajaran yang sesuai, yang mampu membawa peserta didik kepada pencapaian prestasi yang setinggitingginya. Kenyataan di SDN 2 Kabila Kabupaten Bone Bolango, guru masih menggunakan model pembelajaran tradisional. Hal ini berdampak kepada pencapaian prestasi peserta didik yang kurang maksimal.

Salah satu pendekatan pembelajaran yang dianjurkan yakni, pendekatan scientific. Dalam pendekatan scientific menjadikan peserta didik yang diberi tahu menjadi peserta didik yang mencari tahu, dari guru yang merupakan sumber belajar menjadi belajar dari beraneka macam sumber, dari pendekatan tekstual menuju proses sebagai penguatan penggunaan pendekatan ilmiah, dari pembelajaran

\footnotetext{
${ }^{4}$ Kemendikbud, Pengembangan Kurikulum 2013. Paparan Mendikbud dalam Sosialisasi Kurikulum. (Jakarta: Kemendikbud, 2013). h. 3-4.

${ }^{5}$ Kemendikbud, Pendekatan Scientific (ilmiah) dalam Pembelajaran. (Jakarta: Pusbangprodik, 2013). h. 203, 202.
} 
yang menekankan jawaban tunggal menuju pembelajaran dengan jawaban yang kebenarannya multi dimensi, pembelajaran yang mengutamakan pembudayaan dan pemberdayaan peserta didik sebagai pebelajar sepanjang hayat.

\section{Pembelajaran Tematik}

Pembelajaran tematik pada dasarnya merupakan model pembelajaran terpadu dengan menggunakan tema untuk mengaitkan beberapa mata pelajaran sehingga dapat memberikan pengalaman belajar yang bermakna kepada peserta didik. Pembelajaran tematik adalah pembelajaran yang utuh dan menyeluruh sehingga dapat mengembangkan aspek pengetahuan, sikap serta keterampilan oleh peserta didik. Pembelajaran ini menggunakan tema-tema yang dekat dengan kehidupan peserta didik, sehingga pembelajaran dapat lebih bermakna dengan peserta didik mencari sendiri dan menemukan apa yang akan mereka pelajari. ${ }^{6}$

Pembelajaran tematik tidak menghadirkan berbagai mata pelajaran dengan terkotak-kotak, namun berbagai mata pelajaran tersebut dikaitkan dengan topik yang sesuai, dengan demikian sejak dini peserta didik terlatih untuk mengaitkan informasi yang satu dengan yang lain. ${ }^{7}$ Pembelajaran tematik memiliki satu tema yang aktual, juga dekat dengan dunia peserta didik, serta berkaitan dengan kehidupan sehari-hari peserta didik. Tema inilah yang menjadi pemersatu materi yang beragam dari beberapa materi dalam mata pelajaran. ${ }^{8}$

Selanjutnya, Trianto menambahkan bahwa penerapan pembelajaran tematik di sekolah dasar sangat membantu, karena sesuai dengan tingkat perkembangan pada peserta didik yang masih melihat segala sesuatu secara menyeluruh atau holistik. Dengan demikian, peserta didik akan mendapatkan kebulatan dan keutuhan pengetahuan. 9 Pembelajaran tematik merupakan suatu pendekatan pembelajaran yang melibatkan beberapa mata pelajaran untuk memberikan pengalaman yang bermakna bagi peserta didik.

\footnotetext{
${ }^{6}$ Yovita Dian Putranti, 2014, Implementasi Pembelajaran Tematik Integratif Dengan Pendekatan Saintifik Kelas IV B Sd Negeri Percobaan 3 PAIKEM, Skripsi: Program Studi Pendidikan Guru Sekolah Dasar Jurusan Pendidikan Pra Sekolah Dan Sekolah Dasar Fakultas Ilmu Pendidikan Universitas Negeri Yogyakarta, h. 11.

${ }^{7}$ Conny R. Semiwan. Belajar dan Pembelajaran Prasekolah dan Sekolah Dasar. (Jakarta: PT. Indeks, 2008), h. 74.

${ }^{8}$ Trianto. Model Pembelajaran Terpadu. (Jakarta: Bumi Aksara, 2010) h. 57.

${ }^{9} I b i d$, h. 157.
} 
Dikatakan bermakna karena dalam pembelajaran tematik, peserta didik akan memahami konsepkonsep yang mereka pelajari melalui pengalaman langsung dan menghubungkannya dengan konsep yang telah dipahami. ${ }^{10}$

Berdasarkan beberapa pendapat di atas, dapat ditarik kesimpulan bahwa pembelajaran tematik adalah pembelajaran dengan mengintegrasikan materi dari beberapa mata pelajaran ke dalam sebuah tema. Pembelajaran ini melintasi batas-batas mata pelajaran sehingga peserta didik belajar secara utuh dan menyeluruh, oleh karena itu pembelajaran akan lebih bermakana karena juga tema yang digunakan sesuai dengan kehidupan sehari-hari peserta didik. ${ }^{11}$

Pembelajaran yang berkualitas sangat tergantung dari motivasi peserta didik dan kreatifitas pengajar. Pembelajaran yang memiliki motivasi tinggi ditunjang dengan pengajar yang mampu memfasilitasi motivasi tersebut akan membawa pada keberhasilan pencapaian target belajar. Target belajar dapat diukur melalui perubahan sikap dan kemampuan peserta didik melalui proses belajar. Desain pembelajaran yang baik, ditunjang fasilitas yang memandai, ditambah dengan kreatifitas guru akan membuat peserta didik lebih mudah mencapai target belajar. ${ }^{12}$

\section{Implementasi dan Prinsip Pembelajaran Tematik}

Kegiatan implementasi pembelajaran tematik terdiri dari tiga tahapan yaitu kegiatan perencanaan, kegiatan pelaksanaan dan kegiatan penilaian atau evaluasi.

a. Kegiatan perencanaan pembelajaran

Perencanaan adalah suatu cara yang disiapkan agar kegiatan dapat berjalan dengan baik dan dapat mencapai tujuan yang diinginkan. ${ }^{13}$ Kegiatan pembelajaran juga membutuhkan perencanaan yang matang, perencanaan dalam kegiatan pembelajaran berupa pembuatan Rencana Pelaksanaan Pembelajaran (RPP). Rencana pelaksanaan pembelajaran adalah rencana pembelajaran yang dikembangkan secara rinci dari suatu materi pokok atau tema tertentu yang mengacu pada silabus. RPP mencakup: a) data sekolah, mata pelajaran, dan kelas/semester; b) materi pokok; c) alokasi waktu; d)

\footnotetext{
${ }^{10}$ Daryanto, Pembelajaran Tematik, Terpadu, Terintegrasi, h. 3.

${ }^{11}$ Rusman, Op., Cit, h. 137.

${ }^{12}$ Robbins, Stephen P: 2007, http://id.wikipedia.org/wiki/Pembelajaran / Diakses pada 14 April 2017.

${ }^{13}$ Andi Prastowo, Pengembangan Bahan Ajar Tematik Panduan Lengkap Aplikatif, h. 232.
}

288 | Rusni Walangadi 
tujuan pembelajaran, Kompetensi Dasar (KD) dan indikator pencapaian kompetensi; e) materi pembelajaran; metode pembelajaran; f) media, alat dan sumber belajar; g) langkahlangkah kegiatan pembelajaran; dan $\mathrm{h}$ ) penilaian.

b. Kegiatan pelaksanaan pembelajaran

Kegiatan pelaksanaan pembelajaran terdiri dari tiga tahapan yaitu kegiatan pendahuluan, kegiatan inti, dan kegiatan penutup.

1) Kegiatan pendahuluan

Kegiatan pendahuluan bisa disebut juga dengan kegiatan pemanasan. Dalam kegiatan ini guru menggali pengalaman peserta didik tentang tema yang akan disajikan, guru juga harus mampu menarik perhatian peserta didik terhadap tema yang akan diberikan. ${ }^{15}$

2) Kegiatan Inti

Kegiatan inti merupakan proses pembelajaran untuk mencapai tujuan, yang dilakukan secara interaktif, inspiratif, menyenangkan, menantang, memotivasi peserta didik untuk secara aktif menjadi pencari informasi, serta memberikan ruang yang cukup bagi prakarsa, kreativitas, dan kemandirian sesuai dengan bakat, minat dan perkembangan fisik serta psikologis peserta didik. Kegiatan inti menggunakan metode yang disesuaikan dengan karakteristik peserta didik dan mata pelajaran, yang meliputi proses observasi, menanya, mengumpulkan informasi, asosiasi, dan komunikasi. Dalam setiap kegiatan guru harus memperhatikan kompetensi yang terkait dengan sikap seperti jujur, teliti, kerja sama, toleransi, disiplin, taat aturan, menghargai pendapat orang lain yang tercantum dalam silabus dan RPP.

a) Mengamati

Dalam kegiatan mengamati, guru memberi kesempatan peserta didik untuk melakukan pengamatan melalui kegiatan: melihat, menyimak, mendengar, dan membaca.

b) Menanya

14 Peraturan Menteri Pendidikan dan Kebudayaan Republik Indonesia Nomor 81A Tahun 2013, Implementasi Kurikulum Pedoman umum Pembelajaran.

${ }^{15}$ Andi Prastowo, Pengembangan Bahan Ajar Tematik Panduan Lengkap Aplikatif, h. 384.

Jurnal Ilmiah AL-Jauhari Volume 4 No 2, (2019): 284-312 
Setelah peserta didik mengamati, selanjutnya guru membimbing peserta didik untuk mengajukan pertanyaan. Melalui kegiatan bertanya dikembangkan rasa ingin tahu peserta didik. Pertanyaan tersebut menjadi dasar untuk mencari informasi.

c) Mengumpulkan dan mengasosiasikan

Tindak lanjut bertanya adalah menggali dan mengumpulkan informasi dari berbagai sumber melalui berbagai cara. Peserta didik dapat membaca buku yang lebih banyak, memperhatikan objek yang lebih teliti, atau bahkan melakukan eksperimen. Dari kegiatan tersebut terkumpul sejumlah informasi, dan informasi tersebut menjadi dasar bagi kegiatan berikutnya yaitu memroses informasi untuk menemukan keterkaitan satu informasi dengan informasi lainnya,

d) Mengkomunikasikan hasil

Kegiatan berikutnya adalah menuliskan atau menceritakan apa yang ditemukan dalam kegiatan mencari informasi, mengasosiasikan dan menemukan pola. Hasil tersebut disampaikan di kelas dan dinilai oleh guru sebagai hasil belajar.

3) Kegiatan penutup

Dalam kegiatan penutup, guru bersamasama dengan peserta didik membuat rangkuman pelajaran, melakukan penilaian atau refleksi terhadap kegiatan yang sudah dilaksanakan secara konsisten dan terprogram, memberikan umpan balik terhadap proses dan hasil pembelajaran, merencanakan kegiatan tindak lanjut dalam bentuk pembelajaran remedi, program pengayaan, layanan konseling dan memberikan tugas baik tugas individual maupun kelompok sesuai dengan hasil belajar peserta didik, dan menyampaikan rencana pembelajaran pada pertemuan berikutnya. ${ }^{16}$

\section{Pendekatan Scientific dalam Pembelajaran}

Pendekatan scientific menjadikan pembelajaran lebih aktif dan tidak membosankan, peserta didik dapat mengonstruksi pengetahuan dan keterampilannya melalui fakta-fakta yang ditemukan dalam penyelidikan di lapangan guna pembelajaran. Selain itu, dengan

\footnotetext{
${ }^{16}$ Peraturan Menteri Pendidikan dan Kebudayaan Republik Indonesia Nomor 81A Tahun 2013, Implementasi Kurikulum Pedoman umum Pembelajaran.
} 
pembelajaran berbasis pendekatan scientific ini, peserta didik didorong lebih mampu dalam mengobservasi, bertanya, bernalar, dan mengomunikasikan atau mempresentasikan hal-hal yang dipelajari dari fenomena alam ataupun pengalaman langsung ${ }^{17}$.

Pada pembelajaran ekonomi misalnya, peserta didik dapat diajak melihat langsung peristiwa, mengamati kejadian, fenomena, konteks atau situasi yang berkaitan dengan pasar, seperti kegiatan penawaran dan permintaan yang dilakukan oleh penjual dan pembeli. Dengan demikian, peserta didik selalu mengingatnya dan proses pembelajaran terasa lebih berkesan.

Penerapan pendekatan saintifik selain dapat menjadikan peserta didik aktif dalam mengkonstuksikan pengetahuan dan keterampilannya, juga dapat mendorong peserta didik untuk melakukan penyelidikan guna menemukan fakta - fakta dari suatu fenomena atau kejadian, Artinya dalam proses pembelajaran, peserta didik di belajarkan dan di biasakan untuk menentukan kebenaran ilmiah, bukan diajak untuk beropini apalagi fitnah dalam melihat suatu fenomena. Mereka dilatih untuk mampu berfikir logis, runut dan sistematis dengan menggunakan kapasitas berfikir tingkat tinggi (high ordan thingking).

Pendekatan saintifik yaitu proses pembelajaran dimana peserta didik diajak untuk berfikir logis, runut dan sistematis, karena sesunggunya pembelajaran itu sendiri adalah sebuah proses ilmiah (keilmuan).

Sementara kemdikbud (2013) memberikan konsepsi tersendiri bahwa pendekatan saintifik (scientific appoacch) dalam pembelajaran, di dalamnya mencakup komponen : (1) mengamati (observasi). (2) menanya (questioning). (3) menalar (associating). (4) mencoba (experimenting). (5) membentuk jejaring (networking). ${ }^{18}$

Dari pendapat di atas pendekatan saintifik adalah pendekatan dalam proses pembelajaran dimana peserta didik di ajak mengamati suatu obyek yang akan di pelajari dan diberikan kesempatan untuk membuat pertanyaan - pertanyaan yang timbul dari hasil pengamatannya, kemudian peserta didik diberikan keleluasaan untuk melakukan percobaan dengan pengalaman keilmuan yang dimilikinya serta mengelolah hasil dari percobaan yang dilakukan, juga diharapkan peserta didik mampu untuk menyajikan serta menarik

\footnotetext{
${ }^{17}$ Kemendikbud, 2013, h. 203.

${ }^{18}$ Kemendibud. (2013). Kurikulum 2013 (Kompetensi Dasar SD/MI). Diakses dari http://www.pendidikan-diy.go.id/file/mendiknas/kurikulum-2013kompetensi-dasar-sd-ver-3-3 2013.Diakses pada Jum;at 21 Juli 2017.
} 
kesimpulan dari apa yang telah dipelajari, selain itu peserta didik juga dapat menciptakan sesuatu yang dikumpulkan dari fakta - fakta keilmuan yang dimiliki.

Metode saintifik adalah proses berfikir untuk memecahkan masalah secara sistematis, empiris dan terkontrol. Kurikulum 2013 menekankan pada deminsi pedagogic modern dalam pembelajaran yaitu menggunakan pendekatan saintifik. Adapun langkah-langkah saintifik adalah: Mengamati (observasi); Menanya (questionin); Menalar (associating); Mencoba (experimenting); Membentu jejaring (networking). ${ }^{19}$

Slameto (2003: 180) mengatakan suatu minat dapat diekspresikan melalui suatu pernyataan bahwa peserta didik lebih menyukai suatu hal dari pada hal lainnya, dapat pula dimanifestasikan melalui partisipasi dalam suatu aktivitas. Minat tidak dibawa sejak lahir, melainkan diperoleh kemudian. Minat terhadap sesuatu dipelajari dan mempengaruhi belajar selanjutnya serta mempengaruhi minat-minat baru. ${ }^{20}$

Minat dapat merupakan sebab atau akibat dari suatu pengalaman. Oleh karena itu, minat berhubungan dengan dorongan, motif-motif dan responrespon manusia. Ada 3 faktor yang mempengaruhi minat yaitu faktor dorongan atau keinginan dari dalam, faktor motif sosial, dan faktor emosional.

Kehidupan seseorang pada umumnya penuh dorongan dan minat untuk mencapai atau memiliki sesuatu. Perilaku seseorang dan munculnya berbagai kebutuhan disebabkan oleh berbagai dorongan dan minat. Dorongan-dorongan dan minat seseorang itu terpenuhi merupakan dasar dari pengalaman emosionalnya. Seorang individu dalam merespon sesuatu lebih banyak diarahkan oleh penalaran dan pertimbangan-pertimbangan objektif.

Akan tetapi pada saat-saat tertentu di dalam kehidupannya, dorongan emosional banyak campur tangan dan mempengaruhi pemikiranpemikiran dan tingkah lakunya. Oleh karena itu untuk memahami anak/ remaja, perlu mengetahui apa yang ia lakukan dan pikirkan. Disamping itu, hal yang lebih penting untuk diketahui adalah apa yang mereka rasakan. Jadi makin banyak kita memahami dunia anak/remaja , makin perlu kita melihat ke dalam kehidupan emosionalnya dan memahami perasaanperasaannya, baik perasaan

\footnotetext{
${ }^{19}$ Kemendibud. (2013). Kurikulum 2013 (Kompetensi Dasar SD/MI). Diakses dari http://www.pendidikan-diy.go.id/file/mendiknas/kurikulum-2013kompetensi-dasar-sd-ver-3-3 2013.Diakses pada Jum;at 21 Juli 2017.

${ }^{20}$ Slameto, Op.Cit, h. 180.
} 
tentang dirinya sendiri maupun tentang orang lain. Gejala-gejala emosional seperti marah, takut, bangga dan rasa malu, cinta dan benci, harapan-harapan dan rasa putus asa, perlu dicermati dan difahami dengan baik agar proses pembelajaran pendidikan pada anak/remaja dapat berjalan sesuai dengan yang diharapkan.

Walgito berpendapat bahwa motif berasal dari bahasa latin movere yang berarti bergerak atau to move. Karena itu motif diartikan sebagai kekuatan yang terdapat dalam diri organisme yang mendorong untuk berbuat atau merupakan driving force. Motif sebagai pendorong pada umumnya tidak berdiri sendiri, tetapi saling kait-mengait dengan faktor-faktor lain. Hal-hal yang dapat mempengaruhi motif disebut motivasi. Kalau orang ingin mengetahui mengapa orang berbuat atau berperilaku ke arah sesuatu seperti yang dikerjakan, maka orang tersebut akan terikat dengan motivasi atau perilaku yang termotivasi (motivated behavior). Motivasi merupakan keadaan dalam diri individu atau organisme yang mendorong perilaku kearah tujuan. ${ }^{21}$

Dengan demikian dapat dikemukakan bahwa motivasi mempunyai 3 aspek, yaitu: a. Keadaan terdorong dalam diri organisme (a driving state), yaitu kesiapan bergerak karena kebutuhan misalnya kebutuhan jasmani, karena keadaan lingkungan, atau karena keadaan mental seperti berfikir dan ingatan; b. Perilaku yang timbul dan terarah karena keadaan ini; c. Goal atau tujuan yang dituju oleh perilaku tersebut.

Perkembangan teknologi dan ilmu pengetahuan dewasa ini telah mengalami kemajuan yang sangat pesat. Pemerintah juga akan mempercepat pencanangan Millenium Development Goals yang pada awalnya akan dicanangkan pada tahun 2020 dipercepat menjadi tahun 2015. Millenium Development Goals adalah era globalisasi atau era pasar bebas, sebagai era persaingan mutu atau kualitas, siapa yang berkualitas dialah yang akan maju dan mampu mempertahankan eksistensinya.

Perubahan kurikulum di Indonesia akhir-akhir ini berlangsung dengan relatif singkat. Jangka waktu untuk pengimplementasian kurikulum yang satu dengan yang lain juga begitu cepat. Dampak dari perubahan kurikulum ini dirasakan sekali oleh guru dan peserta didik karena mereka adalah subjek utama dalam sebuah pendidikan di sekolah. Sosialisasi mengenai kurikulum baru yang akan diberlakukan membutuhkan banyak waktu, sedangkan proses pendidikan tetap berjalan tanpa henti. Sekolah-sekolah yang telah mendapatkan

\footnotetext{
${ }^{21}$ Walgito, 2002, Berbagai Masalah Pendekatan dalam Proses Belajar Mengajar. Jakarta: Bina Aksara, h. : 168-169).
} 
sosialisasi dari kurikulum baru ini dapat dengan segera menerapkannya, namun sekolah-sekolah di pelosok masih harus menunggu sosialisasi kurikulum baru itu sampai di daerah mereka. Dengan demikian, pemerataan mengenai kurikulum baru kurang dapat dirasakan secara bersama-sama.

Dalam pembelajaran tematik integratif ini peserta didik diminta aktif untuk belajar, beberapa peserta didik masih ada yang malu ataupun tidak percaya diri untuk menyampaikan pendapatnya, sehingga peserta didik tersebut harus menghampiri gurunya dan bertanya dengan cara berbisik. Peserta didik yang aktif bertanya juga peserta didik tertentu saja. Pendekatan saintifik dalam proses pembelajaran telah dilaksanakan seperti mengamati gambar, mencoba membuat wayang dari ranting daun ketela, dan menyimpulkan informasi yang telah diperoleh.

\section{Penerapan Model Pembelajaran Tematik dalam Pendekatan Scientific}

Sebelum peneliti membahas bagaimana penerapan model pembelajaran tematik dalam pendekatan Scientific untuk meningkatkan minat belajar peserta didik di SDN 2 Kabila Kabupaten Bone Bolango, terlebih dahulu disampaikan kondisi pembelajaran di SDN 2 Kabila Kabupaten Bone Bolango itu sendiri, sebagaimana pernyataan yang dikemukakan kepala sekolah sebagai berikut: ${ }^{22}$

"Kebetulan di sekolah ini pararel jadi kan ada empat kelas, selain di awalawal itu saya melihat dilapangan seperti apa, ohh pembelajaran diluar kelas seperti apa. Alhamdulilah mereka tidak ada kesulitan, memang di awal-awal bingung tapi setelah satu semester saya tanya saya ikuti alhamdulilah mereka, menurut info yang disampaikan kepada saya tidak masalah justru anak-anak itu enjoy aja".

Selain itu, hal tersebut juga diperkuat dengan data hasil observasi yang peneliti dimana pembelajaran tematik telah diimplementasikan di sekolah tersebut. Peserta didik belajar dengan menggunakan tema, sub tema dan pembelajaran sesuai yang tertera di dalam buku pegangan peserta didik. Guru kelas menggunakan pedoman buku pegangan guru untuk mengajar.

Sebagaimana telah disebutkan sebelumnya bahwa pembelajaran Tematik merupakan suatu penyajian pembelajaran yang

\footnotetext{
${ }^{22}$ Hasil wawancara bersama Kasna Daud, S.Pd (Kepala SDN 2 Kabila Kabupaten Bone Bolango), Rabu 19 April 2017.
} 
menyatukan beberapa mata pelajaran dengan Tema sebagai pemersatunya.

"Sementara karakteristik keilmuan dari setiap materi pelajaran tidaklah sama maka khusus untuk penyajian pembelajaran tematik dapat disajikan langkah dalam pendekatan ilmiah yakni, mengamati, Menanya, Menalar, Mencoba, Mengolah, Menyimpulkan, Menyajikan, dan Mengkomunikasikan". ${ }^{23}$

Pembelajaran tematik di sekolah dasar merupakan suatu hal yang dapat dianggap relatif baru dan pemahamannya oleh guru belum mendalam, sehingga dalam implementasinya belum sesuai dengan yang diharapkan. Masih banyak guru yang merasa sulit dalam melaksanakan pembelajaran tematik ini. Hal ini terjadi antara lain karena guru belum mendapat pelatihan secara intensif tentang pembelajaran tematik ini. Di samping itu juga guru masih sulit meninggalkan kebiasan kegiatan pembelajaran yang penyajiannya berdasarkan mata pelajaran/bidang studi.

Pelaksanaan pembelajaran tematik di sekolah dasar pada saat ini difokuskan pada kelas awal yaitu kelas I, II, dan III atau kelas yang anak-anaknya masih tergolong pada anak usia dini, walaupun sebenarnya pendekatan pembelajaran tematik ini bisa dilakukan di semua kelas. Berikut Analisis penerapan model pembelajaran tematik dalam pendekatan Scientific untuk meningkatkan minat belajar peserta didik di SDN 2 Kabila Kabupaten Bone Bolango sebagaimana berikut ini :

1. Menetapkan Mata Pelajaran yang akan dipadukan

Pada hasil penelitian, dimana tahap ini dilakukan setelah membuat pemetaan kompetensi dasar secara menyeluruh pada semua mata pelajaran yang diajarkan SDN 2 Kabila Kabupaten Bone Bolango dengan maksud supaya terjadi pemerataan keterpaduan dan pencapaiannya. Pada saat menetapkan beberapa mata pelajaran yang akan dipadukan sudah disertai dengan alasan atau rasional yang berkaitan dengan pencapaian dasar oleh peserta didik dan kebermaknaan belajar.

2. Mempelajari Kompetensi dasar dan Indikator dari mata Pelajaran yang akan Dipadukan

Pada tahap ini dilakukan pengkajian atas kompotensi dasar pada jenjang dan kelas yang sama dari beberapa mata pelajaran yang memungkinkan untuk diajarkan dengan menggunakan payung sebuah tema pemersatu. Sebelumnya perlu ditetapkan terlebih

\footnotetext{
${ }^{23}$ Hasil wawancara bersama Kasna Daud, S.Pd (Kepala SDN 2 Kabila Kabupaten Bone Bolango), Rabu 19 April 2017.
} 
dahulu aspek - aspek dari setiap mata pelajaran yang dapat dipadukan,

3. Memilih dan Menetapkan tema.

Tahap berikutnya, yaitu memilih dan menetapkan tema yang dapat mempersatukan kompetensi-kompetensi dasar dan indikator pada setiap mata pelajaran yang akan dipadukan pada kelas dan semester yang sama. Dalam memilih dan menetapkan tema terdapat beberapa hal yang perlu mendapatkan pertimbangan, diantaranya: a. Tema yang dipih harus memungkinkan terjadinya proses berfikir pada diri peserta didik serta terkait dengan cara dan kebiasaan belajarnya; b. Ruang lingkup tema disesuaikan dengan usia dan perkembangan peserta didik, termasuk minat, kebutuhan dan kemampuannya; c. Penetapan tema dimulai dari lingkungan yang terdekat dan dikenali oleh peserta didik.

Tema-tema pemersatu yang akan dibahas dalam pembelajaran tematik bisa ditetapkan sendiri oleh guru dan/atau bersama peserta didik berdasarkan pertimbangan-pertimbangan tersebut. Contohnya seperti tema peristiaw alam, keluarga, kebersihan, kesehatan rekreasi, alat transportasi, alat komunikasi, pengalaman dan sebagainya. Ruang lingkup tema yang ditetapkan tidak terlalu luas atau terlalu sempit. Tema yang terlalu luas bisa dijabarkan lagi menjadi anak tema atau subtema yang sifatnya lebih spesifik dan lebih konkret. Anak tema atau subtema tersebut selanjutnya dapat dikembangkan lagi menjadi suatu materi/isi pembelajaran.

Berdasarkan hal tersebut, dapat dipahami bahwa Pembelajaran tematik melalui pendekatan scientific mengarahkan peserta didik untuk memiliki kompetensi, sikap, keterampilan, dan pengetahuan jauh lebih baik. Selain itu, peserta didik juga diarahkan untuk menjadi sosok yang tidak hanya asal menerima atau belajar untuk hafal.

Peserta didik akan lebih kreatif, inovatif, dan lebih produktif. Pembelajaran tematik melalui pendekatan scientific memiliki keuntungan yang signifikan dibandingkan dengan model pembelajaran pendekatan tradisional. Penjabaran pendekatan scientific yang dimaksud adalah (1) kemampuan membuat rancangan percobaan; (2) kemampuan melakukan percobaan dan melaporkan hasilnya; (3) pengusaaan konsep proses sains yang baik; dan (4) kemampuan mempresentasikan hasil percobaan dengan baik. ${ }^{24}$

\footnotetext{
${ }^{24}$ Hasil wawancara bersama Kasna Daud, S.Pd (Kepala SDN 2 Kabila Kabupaten Bone Bolango), Rabu 19 April 2017.
} 
Hasil wawancara dan observasi yang telah dilakukan, maka menghasilkan data bahwa menurut peserta didik cara mengajar guru kelas sudah menarik dan menyenangkan. Saat guru mengajukan pertanyaan, peserta didik dengan antusias menjawabnya. Saat guru melakukan ice breaking peserta didik juga mengikutinya dengan semangat, seperti ketika guru meminta peserta didik melakukan tepuk, maka peserta didik yang tadinya ramai akan segera melakukan tepuk tersebut dan kembali duduk ditempatnya masing-masing.

Guru kelas bila mengajar sering diselingi dengan lelucon, sehingga hal ini membuat peserta didik senang selain itu guru kelas ramah dan penuh semangat bila sedang mengajar. Hal ini diperkuat dengan pernyataan peserta didik dari hasil wawancara yang telah peneliti lakukan saat peneliti mengajukan pertanyaan mengenai pendapat peserta didik pada cara mengajar guru kelasnya sebagai berikut.

"Cara ngajarnya menyenangkan, gak pernah marah kok. Menjelaskannya juga bisa paham". ${ }^{25}$ (Hasil wawancara dengan peserta didik lainnya terlampir).

Proses pembelajaran dengan menggunakan pendekatan scientific terdiri atas enam pengalaman belajar pokok, yang terdiri dari:

1. Mengamati: membaca, mendengar, menyimak, melihat (tanpa atau dengan alat) untuk mengidentifikasi masalah yang ingin diketahui.

2. Menanya mengajukan pertanyaan tentang informasi yang tidak dipahami dari apa yang diamati atau pertanyaan untuk mendapatkan informasi tambahan tentang apa yang diamati (dimulai dari pertanyaan faktual sampai ke pertanyaan yang bersifat hipotetik)

3. Mencoba/mengumpulkan data (informasi): melakukan eksperimen, membaca sumber lain dan buku teks, mengamati objek/kejadian/aktivitas, wawancara dengan nara sumber.

4. Mengasosiasikan/mengolah informasi: mengolah informasi yang sudah dikumpulkan baik terbatas dari hasil kegiatan mengumpulkan/eksperimen mau pun hasil dari kegiatan mengamati dan kegiatan mengumpulkan informasi.

5. Mengkomunikasikan: Menyampaikan hasil pengamatan, kesimpulan berdasarkan hasil analisis secara lisan, tertulis, atau media lainnya

\footnotetext{
${ }^{25}$ Hasil wawancara bersama Nisa (Peserta Didik SDN 2 Kabila Kabupaten Bone Bolango), Rabu 19 April 2017.
} 
6. (Dapat dilanjutkan dengan) Mencipta: menginovasi, mencipta, mendisain model, rancangan, produk (karya) berdasarkan pengetahuan yang dipelajari. Kegiatan pembelajaran meliputi tiga kegiatan pokok, yaitu kegiatan pendahuluan, kegiatan inti, dan kegiatan penutup. Kegiatan pendahuluan bertujuan untuk menciptakan suasana awal pembelajaran yang efektif yang memungkinkan peserta didik dapat mengikuti proses pembelajaran dengan baik. Kegiatan inti merupakan kegiatan utama dalam proses pembelajaran atau dalam proses penguasaan pengalaman belajar (learning experience) peserta didik. Kegiatan penutup ditujukan untuk dua hal pokok. Pertama, validasi terhadap konsep, hukum atau prinsip yang telah dikonstruk oleh peserta didik. Kedua, pengayaan materi pelajaran yang dikuasai peserta didik.

Setiap kegiatan yang dilakukan peserta didik akan menghasilkan suatu perubahan pada dirinya. Perubahan tersebut meliputi ranah kognitif, afektif dan psikomotorik. Hasil belajar yang diperoleh peserta didik diukur berdasarkan perbedaan tingkah laku sebelum dan sesudah belajar dilakukan. Salah satu indicator terjadinya perubahan hasil belajar di sekolah adalah proses belajar yang dapat dilihat melalui angka-angka di dalam rapor atau daftar nilai yang diperoleh peserta didik pada akhir semester.

Winkel mengatakan "prestasi adalah bukti keberhasilan yang telah dicapai". Sedangkan belajar merupakan suatu perubahan dalam tingkah laku yang merupakan hasil dari pengalaman. Dengan demikian prestasi belajar adalah bukti keberhasilan yang telah dicapai yang merupakan hasil dari pengalaman. ${ }^{26}$

Menurut Tu'u bahwa menyatakan prestasi belajar merupakan penguasaan pengetahuan atau keterampilan yang dikembangkan oleh mata pelajaran yang lazimnya ditunjukkan dengan nilai tes atau angka yang diberikan oleh guru. ${ }^{27}$

Prestasi belajar merujuk pada apa yang mampu dilakukan oleh seseorang dan seberapa baik ia melakukannya dalam menguasai bahan-bahan dan materi ajar yang telah diajarkan. Dengan demikian maka pengertian prestasi belajar yaitu "hasil yang dicapai oleh seseorang dalam usaha belajar sebagaimana yang dinyatakan dalam rapor". Sedangkan Gintings mengemukakan "prestasi belajar peserta didik adalah hasil berbagai upaya dan daya yang tercermin dari

\footnotetext{
${ }^{26}$ W.S. Winkel, 1996. Psikologi Pengajaran, Jakarta: Grasindo, h. 16.

${ }^{27}$ Tu'u, Tulus. 2004. Peran Disiplin Pad Perilaku Dan Prestasi Peserta didik. Jakarta: PT. Bumi Aksara, h. 75.
} 
partisipasi belajar yang dilakukan peserta didik dalam mempelajari materi pelajaran yang diajarkan oleh guru". ${ }^{28}$

Dalam hubungan dengan pelajaran di sekolah, prestasi belajar yang diperoleh meliputi semua mata pelajaran, misalnya prestasi peserta didik pada mata pelajaran ekonomi. Prestasi belajar ekonomi adalah hasil yang telah dicapai setelah menguasai pengetahuan atau keterampilan dalam pelajaran ekonomi pokok bahasan pasar yang ditunjukkan dengan nilai tes atau angka yang diberikan oleh guru.

Semakin tinggi nilai yang dihasilkan maka semakin baik pula prestasi belajar yang didapatkan. Prestasi belajar tersebut dapat diamati dari ketercapaian hasil belajar peserta didik yang ditentukan oleh Kriteria Ketuntasan Minimum (KKM). Melalui KKM tersebut dapat diketahui tinggi rendahnya nilai peserta didik yang diperoleh dan menunjukkan tingkat prestasi belajar peserta didik. Menurut Muhibbin Syah faktor-faktor yang mempengaruhi prestasi belajar dapat dikelompokkan menjadi tiga macam, antara lain sebagai berikut: ${ }^{29}$

1. Faktor internal (faktor dari dalam peserta didik), yakni keadaan/kondisi jasmani dan rohani peserta didik, antara lain tingkat kecerdasan/intelegensi peserta didik, sikap peserta didik, bakat peserta didik, minat peserta didik, dan motivasi peserta didik.

2. Faktor eksternal (faktor dari luar diri peserta didik), yaitu kondisi lingkungan di sekitar peserta didik, yang terdiri dari lingkungan sosial dan lingkungan nonsosial.

3. Faktor pendekatan belajar (approach to learning), yakni jenis upaya belajar peserta didik yang meliputi strategi dan metode yang digunakan peserta didik untuk melakukan kegiatan pembelajaran materi-materi pelajaran.

4. Jadi, keberhasilan peserta didik selain dipengaruhi oleh beberapa faktor di atas namun sangat dipengaruhi juga oleh intelegensi, hal ini dikarenakan intelegensi merupakan salah satu faktor yang sangat mempengaruhi tinggi rendahnya prestasi belajar. Intelegensi merupakan dasar potensial bagi pencapaian hasil belajar, di mana hasil belajar yang akan dicapai tergantung pada tingkat intelegensi. Jika intelegensi tinggi, maka kemungkinan prestasi belajar peserta didik yang diraih juga tinggi, dan semakin

\footnotetext{
${ }^{28}$ Gintings, Abdorakhman. 2010. Esensi Praktis Belajar Dan Pembelajaran. Bandung: Humaniora, h. 87.

${ }^{29}$ Muhibbin Syah, 2005, Peran Disiplin Pada Perilaku Dan Prestasi Peserta didik. Jakarta: PT. Bumi Aksara, h. 132.
} 
tinggi motivasi yang dimiliki peserta didik maka prestasi belajar yang akan diraih tinggi. ${ }^{30}$

Karakteristik pembelajaran terkait erat dengan Standar Kompetensi Lulusan dan Standar Isi. Standar Kompetensi Lulusan memberikan kerangka konseptual tentang sasaran pembelajaran yang harus dicapai, dan Standar Isi memberikan kerangka konseptual tentang kegiatan belajar dan pembelajaran yang dikembangkan dari tingkat kompetensi dan ruang lingkup materi. Sesuai dengan Standar Kompetensi Lulusan, sasaran pembelajaran mencakup pengembangan domain sikap, pengetahuan, dan keterampilan yang memiliki karakteristik berbeda untuk masing-masing mata pelajaran.

Sikap diperoleh melalui aktivitas menerima, menjalankan, menghargai, menghayati, dan mengamalkan. Pengetahuan diperoleh melalui aktivitas mengingat, memahami, menerapkan, menganalisis, mengevaluasi, dan mencipta. Keterampilan diperoleh melalui aktivitas mengamati, menanya, mencoba, menalar, menyaji, dan mencipta. Pencapaian kompetensi tersebut berkaitan erat dengan proses pembelajaran yang dilaksanakan. Oleh sebab itu, guru harus merencanakan pembelajaran sesuai tuntutan kurikulum dengan menggunakan pendekatan scientific dan model pembelajaran yang mendorong kemampuan peserta didik untuk melakukan penyingkapan/penelitian, serta dapat menghasilkan karya kontekstual, baik individual maupun kelompok. ${ }^{31}$

Pembelajaran scientific merupakan pembelajaran yang mengadopsi langkah-langkah saintis dalam membangun pengetahuan melalui metode ilmiah. Pembelajaran tersebut tidak hanya memandang hasil belajar sebagai muara akhir, tetapi proses pembelajaran dipandang sangat penting. Pendekatan ini menekankan pada proses pencarian pengetahuan, berkenaan dengan materi pembelajaran melalui berbagai kegiatan, yaitu mengamati, menanya, mengeksplor/mengumpulkan informasi/mencoba, mengasosiasi, dan mengomunikasikan.

Data penelitian diperoleh dengan menggunakan metode wawancara, observasi, dokumentasi, serta catatan lapangan. Kemudian hasil penelitian di analisis oleh peneliti dengan

${ }^{30}$ Nurindah Bau, Penerapan Nilai-Nilai Pendidikan Antikorupsi di Madrasah Tsanawiyah Al-Yusra Gorontalo. Jurnal Ilmiah AL-Jauhari: Jurnal Studi Islam Dan Interdisipliner, 3(1), (2018), 79-96.

${ }^{31}$ Yeni Hamdjati, dan Haluty Djailani, "Peranan Wanita Karier terhadap Pembinaan Kecerdasan Spiritual dan Pembentukan karakter Anak di Kecamatan Tapa Kabupaten Bone Bolango". Jurnal Ilmiah AL-Jauhari: Jurnal Studi Islam dan Interdisipliner 3, no. 2 (February 11, 2019): 103-125. 
menggunakan teknik deskriptif kualitatif, yang artinya peneliti akan menggambarkan, menguraikan, serta menginterpretasikan seluruh data yang terkumpul sehingga mampu memperoleh gambaran secara umum dan menyeluruh.

\section{Pelaksanaan Pembelajaran Tematik dengan Pendekatan Scientific di SDN 2 Kabila Kabupaten Bone Bolango}

Berdasarkan data hasil observasi tentang proses pembelajaran yang dilakukan oleh guru di SDN 2 Kabila Kabupaten Bone Bolango, dapat disimpulkan bahwa guru di SDN 2 Kabila Kabupaten Bone Bolango sudah paham tentang istilah pembelajaran tematik dengan pendekatan scientific. Dalam penerapan pembelajaran dengan pendekatan scientific pun guru juga sudah mampu menerapkannya sesuai dengan keterampilan ilmiah yang ada dalam pendekatan scientific.

Berikut contoh guru dalam melatih keterampilan ilmiah aspek mengamati pada tema 8 tentang "lingkungan tempat tinggalku". Peserta didik diajak untuk mengamati gambar denah yang ada di buku peserta didik, kemudian peserta didik diajak untuk menentukan arah, apakah ke arah timur, selatan, barat, ataupun utara. ${ }^{32}$ Dengan mengamati gambar peserta didik secara langsung dapat menceritakan kemana arah mata angin apabila akan pergi ke pusat suatu tempat. Pemilihan model pembelajaran guna menunjang keberhasilan pembelajaran tematik dengan pendekatan scientific.

Dalam pemilihan model pembelajaran tematik dilakukan oleh guru sesuai dengan karakteristik peserta didik dan materi/tema yang akan disampaikan kepada peserta didik. Dengan menggunakan model pembelajaran tersebut peserta didik di SDN 2 Kabila Kabupaten Bone Bolango menjadi lebih aktif dan berpikir kritis.

"Dengan model pembelajaran tematik dalam pendekatan scientific ini, dimana kami sebagai peserta didik tidak merasa bosan dan monoton ketika menyampaikan materi pembelajaran". 33

Peserta didik tidak sungkan-sungkan untuk selalu bertanya kepada guru apabila menemui permasalahan yang sulit dipecahkan oleh peserta didik. Ketika peserta didik sedang mengamati gambar denah yang ada di buku peserta didik tentang arah mata angin, peserta didik saling berebut untuk mengemukakan pendapatnya, apabila ada

\footnotetext{
${ }^{32}$ Hasil wawancara bersama Dra. Sintje S. Leloki (Guru kelas SDN 2 Kabila Kabupaten Bone Bolango), Rabu 19 April 2017.

${ }^{33}$ Hasil wawancara bersama Nur Azizah (Peserta Didik SDN 2 Kabila Kabupaten Bone Bolango), Rabu 19 April 2017.
} 
peserta didik dalam mengemukakan jawaban atau pendapat kurang tepat selalu ada peserta didik yang mencoba untuk memperbaikinya atau mengklarifikasi lebih jelas lagi. ${ }^{34}$

"Tentu dengan adanya pelaksanaan pembelajaran tematik dengan pendekatan scientific ini kami sebagai peserta didik tidak sungkan-sungkan untuk selalu bertanya kepada guru apabila menemui permasalahan yang sulit dipecahkan oleh kami selaku peserta didik". 35

Berdasarkan data dari hasil pengamatan peneliti, di SDN 2

Kabila Kabupaten Bone Bolango dalam pelaksanaan pembelajaran tematik dengan pendekatan scientific secara umum sudah membagi ke dalam 5 tahapan keterampilan ilmiah, yaitu mengamati, menanya, menalar (menalar, mengolah), mencoba, membentuk jejaring (menyimpulkan, menyajikan, dan mengkomunikasikan).

Dalam setiap pelaksanaan pembelajaran tematik dengan pendekatan scientific tidak semua keterampilan ilmiah dalam pendekatan scientific dapat dilatihkan kepada peserta didik, hal ini dikarenakan dalam setiap tema yang diajarkan kepada peserta didik materinya tidak mencakup keterampilan ilmiah tersebut.

Dalam tahapan pelaksanaan pembelajaran tematik dengan pendekatan scientific pada SDN 2 Kabila Kabupaten Bone Bolango guru selalu berusaha semaksimal mungkin untuk membagi 5 keterampilan ilmiah pada setiap pembelajaran, yaitu mengamati, menanya, menalar (menalar, mengolah), mencoba, membentuk jejaring (menyimpulkan, menyajikan, dan mengkomunikasikan).

Berdasarkan dari data hasil pengamatan, di SDN 2 Kabila Kabupaten Bone Bolango dalam mengikuti prosedur pelaksanaan kegiatan pembelajaran tematik dengan pendekatan scientific guru sudah mengikuti dengan baik sesuai dengan prosedur yang telah ditetapkan, yaitu selalu melatihkan keterampilan ilmiah yang ada dalam pendekatan scientific.

Berikut ini adalah deskripsi tentang pelaksanaan pembelajaran tematik dengan pendekatan:

1. Keterampilan Ilmiah Mengamati

Keterampilan ilmiah aspek mengamati mampu dibangun oleh guru di SDN 2 Kabila Kabupaten Bone Bolango secara baik, dalam hal mengindentifikasi objek guru mampu mengajak peserta didik untuk bersama-sama melakukan identifikasi objek yang akan

\footnotetext{
${ }^{34}$ Hasil wawancara bersama Sri Agustin Husain Panani, S.Pd (Guru kelas SDN 2 Kabila Kabupaten Bone Bolango), Rabu 19 April 2017.

${ }^{35}$ Hasil wawancara bersama Alfret (Peserta Didik SDN 2 Kabila Kabupaten Bone Bolango), Rabu 19 April 2017.
} 
dipelajari. Pengidentifikasian objek dilakukan oleh guru ketika pembelajaran akan dimulai sehingga hal ini mampu mendorong peserta didik untuk menemukan fakta tentang apa yang akan dipelajari dengan menggunakan panca indera dari masing-masing peserta didik (melihat, mendengar, menyimak, dan membaca).

Sedangkan dalam indikator menjelaskan peralatan secara akurat, guru tidak selalu melakukannya. Karena menurut beliau tidak semua peralatan yang dipergunakan dalam pembelajaran harus dijelaskan secara rinci, hanya beberapa peralatan saja yang tidak dimengerti oleh peserta didik.Untuk indikator ini (menjelaskan peralatan secara akurat) peneliti bertanya kepada guru di SDN 2 Kabila Kabupaten Bone Bolango. ${ }^{36}$

2. Keterampilan Ilmiah Menanya

Pada aspek menanya pun guru sudah melakukan dengan baik, karena guru mampu mengembangkan ranah sikap sehingga dapat menginspirasi peserta didik dan membangkitkan keterampilan peserta didik dalam berbicara, banyak peserta didik sudah mampu berbicara dengan baik dan tidak terbata-bata.

Untuk mendorong peserta didik dalam berdiskusi guru di SDN 2 Kabila Kabupaten Bone Bolango sudah mampu dan terlihat mampu ketika mendorong peserta didik dalam berdiskusi. Hal ini dikarenakan keseluruhan peserta didik merasa senang dengan setiap pembelajaran yang disampaikan dan senang pula apabila melakukan diskusi. Dalam melakukan kegiatan diskusi, peserta didik tidak pernah memilih-milih siapa saja yang akan dijadikan bagian dari kelompok. Peserta didik sudah menyetujui keputusan yang diambil oleh guru dalam pemilihan anggota kelompok.

Hal ini berpengaruh dengan kinerja peserta didik saat melakukan diskusi, ketika peserta didik merasa tidak terbebani dengan anggota kelompoknya maka dalam forum diskusi peserta didik akan mampu saling bekerja sama satu sama lain. Berbeda dengan peserta didik yang merasa terbebani dengan anggota kelompoknya, maka dalam forum diskusi peserta didik susah untuk membangun kesolidan tim diskusi. Sedangkan dalam hal kesantunan berbicara peserta didik, guru kurang memperhatikan atau belum mampu melatih kesantunan peserta didik dalam berbicara, karena menurut hasil observasi tidak semua peserta didik dalam berbicara atau mengungkapkan pendapat berbicara dengan santun, banyak peserta didik ketika melakukannya langsung berteriak dan tidak mengacungkan jarinya.

\footnotetext{
${ }^{36}$ Hasil wawancara bersama Karmila Musa, S.Pd (Guru kelas SDN 2 Kabila Kabupaten Bone Bolango), Rabu 19 April 2017.
} 


\section{Keterampilan Ilmiah Menalar}

Sedangkan aspek menalar guru belum melakukan secara baik, seringkali guru dihadapkan dengan permasalahan/pertanyaan dari peserta didik dan guru belum mampu menjawab permasalahan/ pertanyaan yang dihadapi secara akurat, sehingga peserta didik masih bertanya-tanya sendiri.

Pada saat peneliti bertanya langsung kepada guru di SDN 2 tentang keterampilan ilmiah menalar belum dilatihkan dengan baik, beliau hanya menjawab karena dalam tema lingkungan tempat tinggalku ini hanya ada satu kegiatan yang menuntut guru untuk melatihkan keterampilan ilmiah. Pada tema 8 "lingkungan tempat tinggalku" karena guru belum merumuskan hipotesis dalam setiap permasalahan/pertanyaan yang ada, maka guru pun juga belum merumuskan kesimpulan sementara berdasarkan bukti/ fakta dari pengujian hipotesis.

Akan tetapi hanya saja terkadang guru merasa kesulitan untuk mendiagnosis kesulitan belajar peserta didik.Karena ketika peserta didik ditanya oleh guru tentang pembelajaran yang telah dilakukan peserta didik selalu menjawab sudah jelas. Guru di SDN 2 mengemukakan bahwa, dalam mendiagnosis kesulitan belajar pada peserta didik beliau selalu berusaha untuk mendiagnosis kesulitan yang di alami oleh peserta didik beliau, tetapi ada kendala ketika beliau melakukan hal itu.

Kendala tersebut adalah ketika peserta didik ditanya apakah sudah paham dengan pembelajaran yang sudah diberikan, mereka selalu menjawab sudah paham, tapi ketika diberi soal atau diberi pertanyaan mereka malah menjawab tidak tahu bahkan ada yang hanya diam saja. Sehingga kegiatan mendiagnosis peserta didik menjadi terhambat, karena tidak bisa langsung ditemukan.

4. Keterampilan Ilmiah Mencoba

Aspek mencoba kurang dominan dilakukan oleh guru, karena tidak semua tema yang diajarkan terdapat aspek mencoba/eksperimen.Tetapi ketika ada tema yang mengharuskan peserta didik untuk bereksperimen, guru mampu mengembangkan kreatifitas peserta didik untuk bereksperimen secara baik. Guru mampu menjelaskan materi secara baik, sehingga peserta didik dalam melakukan eksperimen tidak terjadi kendala yang berarti.

Guru juga sudah mampu dalam memilih tipe tindakan yang tepat dan memilih bagian tindakan dengan tepat, akan tetapi guru tidak selalu mengembangkan cara dalam membuat pertanyaan. Dalam menggunakan peralatan dengan berbagai cara, guru sudah mampu melakukannya, beliau tidak hanya terpatok dengan cara yang ada di

\section{Rusni Walangadi}


buku, tetapi beliau mampu menggunakan cara yang lain agar lebih menyenangkan dalam bereksperimen. ${ }^{37}$

Selain di atas, guru juga sudah mampu menyusun rencana bagaimana mencari informasi dan mampu merumuskan kesimpulan berdasarkan bukti yang ada, sehingga tidak terjadi kekeliriuan informasi atau kesalahpahaman.

5. Keterampilan Ilmiah Membentuk Jejaring

a) Menyimpulkan

Pada keterampilan ilmiah membentuk jejaring (menyimpulkan) guru sudah menjalankannya.Indikator tentang menjelaskan hubungan diantara objek dan kejadian dalam pengamatan guru pun sudah melakukan dengan baik, begitu pun ketika membuat kesimpulan. Guru selalu menggunakan seluruh informasi yang diperoleh dengan tepat agar tidak terjadi kesimpangsiuran dalam penginformasian kepada peserta didik.

b) Menyajikan

Berdasarkan hasil pengamatan yang dilakukan oleh peneliti kepada guru di SDN 2 Kabila Kabupaten Bone Bolango, dalam setiap akhir pembelajaran beliau selalu mengemukakan pendapat dari kesimpulan yang sudah ada secara lisan dan jelas.

c) Mengkomunikasikan

Dalam setiap pembelajaran guru selalu berusaha mengkomunikasikan tema/ materi yang diberikan dengan peserta didik secara baik, hal ini dilakukan agar peserta didik mampu memahami setiap materi yang diberikan oleh guru. Setiap pembelajaran guru pun selalu mengidentifikasikan objek dan kejadian secara akurat, tidak hanya itu beliau juga selalu berusaha menjelaskan setiap objek dan kejadian yang dipelajari secara runtut dan jelas agar peserta didik mampu memahami tema/ materi yang diberikan oleh guru dan tercapai keberhasilan dalam pembelajaran. Secara keseluruhan keterampilan ilmiah membentuk jejaring mampu dilakukan oleh guru secara baik, tetapi ada salah satu keterampilan ilmiah yang dominan pada keterampilan ilmiah membentuk jejaring ini yaitu, keterampilan mengkomunikasikan. Dengan keterampilan mengkomunikasikan guru dapat melatih peserta didik untuk percaya diri dan yakin dengan hasil belajarnya.

Adapun model pembelajaran tematik yang diberikan kepada peserta didik sebagai penunjang keberhasilan pelaksanaan

${ }^{37}$ Hasil wawancara bersama Marni Musa, S.Pd (Guru kelas SDN 2 Kabila Kabupaten Bone Bolango), Rabu 19 April 2017. 
pendekatan scientific adalah Problem Based Learning, walaupun memang ada model pembelajaran lainnya yang digunakan oleh guru seperti model pembelajaran Discovery Learning, model pembelajaran Project Based Learning dll, tetapi yang paling dominan atau yang sering digunakan oleh guru di SDN 2 Kabila Kabupaten Bone Bolango adalah model pembelajaran Problem Based Learning.

\section{Resiko Model Pembelajaran Tematik Scientific}

Berdasarkan hasil wawancara peneliti dengan guru di SDN 2 Kabila Kabupaten Bone Bolango tentang faktor penghambat dalam pelaksanaan model pembelajaran tematik dengan pendekatan scientific, beliau mengungkapkan seringnya yang menjadi penghambat dalam pelaksanaan pembelajaran kepada peserta didik adalah alokasi waktu pembelajaran yang menurut beliau tidak sesuai dengan materi, karena materi dalam setiap tema dan sub tema membutuhkan waktu yang cukup lama agar peserta didik secara keseluruhan mampu mengerti dan paham dengan pembelajaran yang disampaikan oleh guru. ${ }^{38}$

Sementara itu menurut pandangan Kepala Sekolah bahwa:

"Daya pikir peserta didik yang berbeda-beda juga menjadi penghambat dalam pelaksanaan pembelajaran dengan pendekatan scientific, terkadang beberapa peserta didik sudah paham dengan apa yang disampaikan oleh guru, tetapi tidak sedikit pula peserta didik yang hanya diam saja dan hal ini yang membuat peserta didik belum menguasai atau belum memahami keterampilan ilmiah yang dilatihkan oleh guru". ${ }^{39}$

Upaya yang guru lakukan ketika menemukan peserta didik belum menguasai keterampilan ilmmiah yang dilatihkan oleh guru yaitu, guru akan mengadakan remidiasi dari Kompetensi Dasar atau keterampilan ilmiah yang belum dikuasai peserta didik hingga peserta didik tersebut memenhui.

Data yang diperoleh peneliti baik dari hasil wawancara, observasi, dokumentasi, serta catatan lapangan, maka pada pembahasan ini peneliti mendeskripsikan uraian bahasan sesuai dengan rumusan masalah penelitian dan tujuan penelitian tentang Implementasi Pembelajaran tematik dengan Pendekatan Scientific di

\footnotetext{
${ }^{38}$ Hasil wawancara bersama Riska Bokingo, S.Pd (Guru kelas SDN 2 Kabila Kabupaten Bone Bolango), Rabu 19 April 2017.

${ }^{39}$ Hasil wawancara bersama Kasna Daud, S.Pd (Kepala SDN 2 Kabila Kabupaten Bone Bolango), Rabu 19 April 2017.
} 
SDN 2 Kabila Kabupaten Bone diperoleh hasil dari penelitian sebagai berikut: Guru SDN 2 Kabila Kabupaten Bone Bolango Kabupaten sudah memahami istilah pembelajaran tematik integratif dan juga sudah menerapkan tematik integratifdi kelas yang beliau mampu. Guru SDN 2 Kabila Kabupaten Bone Bolango dalam setiap kegiatan pembelajaran selalu berusaha untuk melatihkan keterampilan ilmiah terhadap peserta didik.

Dari hasil wawancara dengan guru di SDN 2 Kabila Kabupaten Bone Bolango dan dengan dibuktikan dari hasil observasi, dokumentasi, dan catatan lapangan untuk prosedur pelaksanaan kegiatan pembelajaran Tematik dengan pendekatan scientific dibagi kedalam 3 tahapan kegiatan, yaitu kegiatan awal, kegiatan inti, serta kegiatan penutup. Setelah dibuktikan dengan hasil observasi, catatan lapangan, serta dokumentasi, guru di SDN 2 Kabila Kabupaten Bone Bolango sudah melaksanakan pembelajaran dengan pendekatan scientific sudah mengikuti prosedur yang telah ditetapkan.

Dalam hal pemilihan media belajar guna mendukung pembelajaran dengan pendekatan scientific berdasarkan hasil wawancara, guru di SDN 2 Kabila Kabupaten Bone Bolango penggunaan media belajar disesuaikan dengan tema/materi yang akan diajarkan. Biasanya mengambil dari media elektronik, media cetak, dan lingkungan sekitar sekolah.Akan tetapi setelah dibuktikan dengan observasi, catatan lapangan, serta dokumentasi, guru di SDN 2 Kabila Kabupaten Bone Bolango lebih sering menggunakan media belajar berupa lingkungan di sekitar sekolah.

Dari hasil wawancara, guru dapat memutuskan peserta didik telah menguasai keterampilan ilmiah dengan melaksanakan ulangan harian, dimana ketika peserta didik memperoleh nilai lebih dari KKM maka peserta didik tersebut dinyatakan sudah menguasai keterampilan ilmiah yang dilatih.Hal ini dibuktikan dengan hasil observasi, dokumentasi, serta catatan lapangan.

\section{Kesimpulan}

Penerapan model pembelajaran tematik dalam pendekatan scientific untuk meningkatkan minat belajar peserta didik di SDN 2 Kabila Kabupaten Bone Bolango adalah pembelajaran terpadu yang menggunakan tema untuk mengaitkan beberapa mata pelajaran sehingga dapat memberikan pengalaman bermakna kepada peserta didik. Karakteristik pembelajaran tematik yaitu: (a) berpusat pada peserta didik, (b) memberikan pengalaman langsung kepada peserta didik, (c) pemisahan antar mata pelajaran tidak nampak, (d) menyajikan konsep dari berbagai mata pelajaran dalam suatu proses 
pembelajaran., (e) bersifat luwes (fleksibel), (f) hasil pembelajaran dapat berkembang sesuai dengan minat dan kebutuhan peserta didik.

Faktor-faktor yang menghambat penerapan model pembelajaran tematik dalam pendekatan scientific untuk meningkatkan minat belajar peserta didik di SDN 2 Kabila Kabupaten Bone Bolango adalah terlalu padatnya materi yang ada dalam setiap tema, sehingga waktu yang sudah ditetapkan dirasa kurang cukup oleh guru. Hal ini terjadi karena pada saat dilakukan penelitian secara bersamaan juga sedang dilakukan pelatihan ujian bagi peserta didik. Upaya yang dilakukan guru adalah dengan melaksanakan tambahan jam belajar diluar jam belajar sekolah, serta meminta kelonggaran waktu pada guru mata pelajaran agama, dan olahraga.

\section{Daftar Pustaka}

Abdul, Majid. Pembelajaran Tematik Terpadu. Bandung: PT Remaja Rosdakarya, 2014.

Prastowo, Andi, Pengembangan Bahan Ajar Tematik Panduan Lengkap Aplikatif.

Arikunto, Suharsimi. Prosedur Penelitian Suatu Pendekatan Praktek. Edisi revisi IV. Bandung: PT Rineka Cipta, 1999.

Jihad Asep \& Haris Abdul. Evaluasi Pembelajaran. Yogyakarta: Multi Pressindo, 2012.

Baldwin, A.L. Theories of Child Development. New York: John Wiley \& Sons, 1967.

Semiwan, Conny R. Belajar dan Pembelajaran Prasekolah dan Sekolah Dasar. Jakarta: PT. Indeks, 2008.

Carin, A.A. \& Sund, R.B. Teaching Science trough Discovery, 3rd Ed. Columbus: Charles E. Merrill Publishing Company, 1975.

Daryanto, Pembelajaran Tematik, Terpadu, Terintegrasi.

Dakir. Perencanaan dan Pengembangan Kurikulum. Jakarta: Rineka Cipta, 2010.

Jerner, Martin David. Elementary Science Methods A Constructivist Approach. Weadsworth Cengage Learning, 2009.

Daryanto. Pendekatan Pembelajaran Scientific Kurikulum 2013. Yogyakarta: Gava Media, 2014.

Fadlillah, M. Implementasi Kurikulum 2013 (Dalam Pembelajaran $S D / M I, S M P / M T S, \& S M A / M A)$. Yogyakarta: Ar-Ruzz Media, 2014. 
Sanapiah Faisol, Mulyadi G Waseso. Metodologi Penelitian Pendidikan. Surabaya: Usaha Nasional, 1982.

Abdorakhman Gintings, Esensi Praktis Belajar Dan Pembelajaran. Bandung: Humaniora, 2010.

Sartinah Hardjono, Prinsip-Prinsip Pengajaran Bahasa dan Sastra Indonesia. Jakarta: Departemen Pendidikan dan Kebudayaan Direktorat Jenderal Pendidikan Tinggi Proyek Pengembangan Lembaga Pendidikan Tenaga Kependidikan, 1988.

Hardini, Isriani dkk. Strategi Pembelajaran Terpadu (Teori, Konsep, \& Implementasi). Yogyakarta: Familia, 2012.

Ismail, Strategi Pembelajaran Agama Islam berbasis Paikem. Semarang: RaSAIL Media Group 2008.

Kunandar. (2013). Penilaian Autentik (Penilaian Hasil Belajar Peserta Didik Berdasarkan Kurikulum 2013). Jakarta: Rajawali Press

Kurniasih, Imas dan Berlin Sani, Implementasi Kurikulum 2013 Konsep dan Penerapan. Surabaya: Kata Pena, 2014.

Kemendibud. Kurikulum 2013 (Kompetensi Dasar SD/MI). Diakses dari $\quad$ http://www.pendidikandiy.go.id/file/mendiknas/kurikulum-2013-kompetensi-dasarsd-ver-3-3 2013.Diakses pada Jum;at 21 Juli 2017.

Moleong Lexi J. Metodelogi Penelitian Kualitatif. Bandung: PT Remaja Rosdakarya, 2007.

Moleong, Lexy J. Metodologi Penelitian Kualitatif. Edisi revisi. Bandung: PT Remaja Rosdakarya. 2005.

Syah Muhibbin, Peran Disiplin Pad Perilaku Dan Prestasi siwa. Jakarta: PT. Bumi Aksara, 2005.

Latifatul Muzamiroh Mida. Kupas Tuntas Kurikulum 2013 (Kelebihan dan Kekurangan Kurikulum 2013). Jakarta: Kata Pena, 2013.

Sukmadinata Nana Syaodih. Metode Penelitian Pendidikan. Bandung: PT Remaja Rosdakarya, 2010.

Nur, M. \& Wikandari, P.R. Pengajaran Berpusat Kepada Peserta didik dan Pendekatan Konstruktivis Dalam Pengajaran. Surabaya: Penerbit: Universitas Negeri Surabaya University Press, 2000

Ngalimun. Strategi dan Model Pembelajaran. Yogyakarta: Aswaja Pressindo, 2013.

Rusman. Manajemen Kurikulum: Seri Manajemen Sekolah Bermutu. Jakarta:PT Raja Grafindo Persada, 2009.

Suparlan, dkk. Pembelajaran Aktif, Kreatif, Efektif, dan Menyenangkan. Bandung: PT. Genesindo, 2008. 
Suryabrata, Sumadi. Metodologi Penelitian. Jakarta: PT Raja Grafindo Persada, 2002.

Sugiyono, Memahami Penelitian Kualitatif. Bandung: Alfabeta, 2012. Trianto. Model Pembelajaran Terpadu. Jakarta: Bumi Aksara, 2010.

Tu'u, Tulus. Peran Disiplin Pad Perilaku Dan Prestasi Peserta didik. Jakarta: PT. Bumi Aksara, 2004.

Habibah, Umi, Penerapan Model PAIKEM untuk Meningkatkan Aktivitas dan Hasil Belajar Matematika Materi Pokok Bangun Datar pada Peserta didik Kelas V Madrasah Ibtidaiyah Nurul Hikmah Krandon Kota Tegal, SKRIPSI: Jurusan Pendidikan Guru Sekolah Dasar Fakultas Ilmu Pendidikan Universitas Negeri Semarang, 2012.

Mohammad, Jauhar Wardati. Implementasi Bimbingan dan Konseling di Sekolah. Prestasi Pustakaraya, Jakarta. 2011.

Winkel W.S. Psikologi Pengajaran, Jakarta: Grasindo, 1996.

Dian Putranti Yovita, Implementasi Pembelajaran Tematik Integratif Dengan Pendekatan Scientific Kelas IV $B$ Sd Negeri Percobaan 3 PAIKEM, Skripsi: Program Studi Pendidikan Guru Sekolah Dasar Jurusan Pendidikan Pra Sekolah Dan Sekolah Dasar Fakultas Ilmu Pendidikan Universitas Negeri Yogyakarta, 2014.

Undang-Undang Dasar Negara Kesatuan Republik Indonesia tahun 1945

Undang-Undang Nomor 20 tahun 2003 tentang Sistem Pendidikan Nasional.

Peraturan Menteri Pendidikan dan Kebudayaan Republik Indonesia Nomor 81 Tahun 2013, Implementasi Kurikulum Pedoman umum Pembelajaran.

www. google.com.search:PAIKEM) Diakses pada Tanggal 10 Oktober 2016.

http:/www.pontianakpost.com) Diakses pada Tanggal 10 Oktober 2016.

http:/pbmtutik.blogspot.com/) Diakses pada Tanggal 10 Oktober 2016.

http://jualbeliforum.com/pendidikan/215357-pengertianimplementasi-menurut-para-ahli.html.20 Agustus 2016. 